\title{
Van Dis is terug
}

\begin{tabular}{|c|c|}
\hline \multicolumn{2}{|l|}{$\begin{array}{l}\text { Book Title: } \\
\text { Ek kom terug }\end{array}$} \\
\hline $\begin{array}{l}\text { EDRIAANV } \\
\text { EKR } \\
\text { TERL }\end{array}$ & $M$ \\
\hline \multicolumn{2}{|c|}{$\begin{array}{l}\text { Author: } \\
\text { Adriaan van Dis }\end{array}$} \\
\hline \multicolumn{2}{|c|}{ ISBN: } \\
\hline \multicolumn{2}{|c|}{$\begin{array}{l}\text { Protea Boekhuis, 2018, } \\
\text { R220* }\end{array}$} \\
\hline \multicolumn{2}{|c|}{$\begin{array}{l}\text { Review Title: } \\
\text { Van Dis is terug }\end{array}$} \\
\hline \multicolumn{2}{|c|}{ Reviewer: } \\
\hline \multicolumn{2}{|c|}{$\begin{array}{l}\text { Affiliation: } \\
\text { 1Private, Potchefstroom, } \\
\text { South Africa }\end{array}$} \\
\hline \multicolumn{2}{|c|}{$\begin{array}{l}\text { Corresponding author: } \\
\text { Henri Nieuwoudt, } \\
\text { hwniewoudt@gmail.com }\end{array}$} \\
\hline \multicolumn{2}{|c|}{$\begin{array}{l}\text { How to cite this book review: } \\
\text { Nieuwoudt, H., 2019, 'Van } \\
\text { Dis is terug', Literator 40(1), } \\
\text { a1585. https://doi.org/ } \\
10.4102 / \text { lit.v40i1.1585 }\end{array}$} \\
\hline \multicolumn{2}{|c|}{$\begin{array}{l}\text { Copyright: } \\
\text { (c) 2019. The Authors. } \\
\text { Licensee: AOSIS. This work } \\
\text { is licensed under the } \\
\text { Creative Commons } \\
\text { Attribution License. }\end{array}$} \\
\hline \multicolumn{2}{|l|}{ Read online: } \\
\hline 口yta & $\begin{array}{l}\text { Scan this QR } \\
\text { code with your } \\
\text { smart phone or } \\
\text { mobile device } \\
\text { to read online. }\end{array}$ \\
\hline
\end{tabular}

In die tragikomiese Ek kom terug (2018), wat deur Daniel Hugo in Afrikaans vertaal is, pak Adriaan van Dis as 't ware die soms esoteriese legkaartstukke van sy bejaarde moeder se vol lewe uit op papier - ongeveinsd en eerlik. Sy dikteer aan hom haar biografie in ruil vir kodisilpille ('Jy kry 'n storie, ek 'n pil', bl. 66) en 'n onverbloemde belofte - om aan haar 'n sagte dood te besorg, al is dit slegs op papier. Sy wil dood wees en haar seun, Van Dis die romanskrywer, is die enigste een wat aan hierdie versoek van haar kan voldoen. Moeder en seun ontwikkel 'n verhouding wat Van Dis soms met meer vrae as antwoorde laat en wat hom met sy eie onsekere herkoms, sy tekortkomings, asook sy eie vrese konfronteer.

In die verhaal word Van Dis self sy ma se narratiewe terapeut ('Het dit jou goed gedoen om te praat?' bl. 52) wat na 'n lang tydperk van swye en onthouding tussen hulle, aandagtig haar ontboesemings transkribeer en haar terugneem: terug na haar jeug, oorloë, die duine, terug na sy eie kinderjare en Nederlands-Indië met 'daardie verdomde kraakkis vol papiere en geheime' (bl. 43). Dit is 'n verhaal wat jou vanaf die voorwoord oriënteer met die oog op die tema van afskeid ('You must sacrifice your family on the altar of fiction', [David Vann]) en hierdie draad word vernuftig regdeur die roman geweef. 'As jy rustig wil doodgaan, moet jy begin om te laat gaan' (bl. 127), maan Van Dis sy ma. Hierteenoor staan die temas van onthou en bewaring. Die kis word van die begin af simbool hiervan, maar ook van die brutale familiekonflik tussen 'n ontwykende moeder, wat haar huisgesin nes 'n kil offisier regeer het, en 'n desperaat-nuuskierige seun. 'As sy maar net ' $n$ bietjie meer van 'n moeder durf wees en daardie innerlike hardheid opsy wil skuif', wens hy (bl. 65).

Alreeds vroeg in hierdie oorwegend waarheidsgegronde en simboliekryke roman, word pynlik sensitiewe temas soos genadedood, enkelouerskap, oorlog en die wroegings van 'n skrywer wat hierdie temas so eerlik moontlik moet weergee, in Van Dis se kenmerkende styl uitgebeeld. 'Is jy van plan om 'n boek oor my te skryf?' (bl. 64), vra Van Dis se moeder skepties toe hy notaboek in die hand met haar kom gesels. 'Miskien, as jy bietjie minder sal lieg', is sy antwoord wat ' $n$ metatekstuele inslag suggereer. Hierdie werk sluit aan by Van Dis se eie (outo)biografiese werk en kan in hierdie verband ook in die breër Nederlandse literatuurmilieu gesitueer word, saam met ontboesemende werke deur skrywers soos Arnon Grunberg, Tom Lanoye, J. Bernlef, J.J. Voskuil en Leo Pleysier, wat ook intieme familie- en veral moeder-seunverhoudings verken.

Van Dis gaan gemaklik en luiters met taal om en vertel reguit, veral ook wat betref onderwerpe wat die leser empaties stem teenoor die 99-jarige moeder wat in haar lewe talryke ontberings moes deurmaak (soos drie oorloë, want 'oud word is ook oorlog' (bl. 59), opstande, trauma en die huisvesting van vlugtelinge). Hy probeer om die vertelling so waarheidsgetrou en gedetailleerd as moontlik te maak, maar die geskiedenis is in vele opsigte weerstandig teen herinterpretasie en 'die verlede maak seer' (bl. 133), en die hede klaarblyklik nog meer so. Hoe meer hy sy moeder daaraan herinner om die waarheid te praat, hoe meer besef hy dat die waarheid 'n onbereikbare ideaal is:

'n Skrywer moet sy hande vuilmaak - in sy kop. Hy gaan op reis agter sy lessenaar, pleeg moorde, verkrag en bemin; hy is die dader en die slagoffer, piel en poesie, swaard en hals. Ervaring voed sy verbeelding en as hy die kans kry, mag hy nie toelaat dat die rou materiaal hom ontglip nie, anders word sy stories te steriel (bl. 38).

Van Dis se moeder wil nie meer lewe nie en vra haar seun herhaaldelik om 'n einde aan haar lewe te maak, want die dokters weier: 'Sy kyk na my op met waterige bruin oë, trek die kussing nader, hou dit voor haar gesig en vra my om dit oor haar mond te druk.' (bl. 127)

Al staan pynlike en persoonlike ontnugterings en bekentenisse oor oorloë en lyding op die voorgrond, is die verhaal steeds nie somber nie en allesbehalwe sentimenteel. Die komiese aspek en wrang humor slaan plek-plek deur en verleen aan Ek kom terug 'n burleske, tragikomiese inslag - hartseer, dog uiters vermaaklik en boeiend. Met 'Jy is ook 'n ongeluk', beken Van Dis 
se ma haar kind se buite-egtelike status en lag luidrugtig daaroor (bl. 80). Uiters gepaste beeldspraak verleen 'n ekstra dimensie aan die verhaal wat dit meer as slegs die woordelikse weergee van 'n lewe maak - dit mak daarvan 'n verlossingsteks: 'Ek sal haar verlos. Verlos van verhale, en as ek dapper genoeg is, sal ek haar verlos van die lewe en haar hand vashou.' (bl. 55)

Daniel Hugo se vertaling behou al hierdie inherente eienskappe van die teks - die naakte feite met intens eerlike taalgebruik wat die leser van meet af intrek en in die sterwensproses van Van Dis se moeder laat deel. Hierdie menslikheid maak van Ek kom terug 'n verhaal waarmee almal wat in 'n ouer-kind-verhouding staan of gestaan het, kan identifiseer.
Van Dis konfronteer die leser met die menslike kondisie feilbaarheid en sterflikheid. Terselftertyd is die teks 'n viering van die lewe, 'n oproep tot aksie en 'n bevestiging van die lewegewende krag van woorde. Ek kom terug is bekroon met die Libris Literatuurprys, wat die inhoud sowel as die styl van die teks in ' $n$ besonder positiewe lig stel en daarvan, veral vir biografieliefhebbers, 'n hoogs aanbevole werk maak.

Ek kom terug is 'n heen-en-weer-spel van skreiende ironie, brandende eerlikheid en 'n leeftyd se herinneringe wat in 'n uiters vermaaklike teks gekondenseer word. Dit is 'n verhaal waarin moeder en seun mekaar fisiek te lyf gaan en stil maak, maar ook vertroetel, verlos en bowenal, aan mekaar 'n stem besorg. 